\title{
МОДИФИКАЦИЯ ФОРМ СОБСТВЕННОСТИ В УСЛОВИЯХ ЦИФРОВИЗАЦИИ ЭКОНОМИКИ *
}

\author{
(C) 2021 Карамова Ольга Владимировна \\ доктор экономических наук, профессор \\ Финансовый университет при Правительстве Российской Федерации, Россия, Москва \\ Email: okaramova@fa.ru \\ ORCID: 0000-0003-3713-7994
}

В статье изучены процессы модификации форм собственности под воздействием технологических и институциональных факторов в условиях цифровой экономики. Анализ форм собственности произведен в методологии институциональной теории и радикального институционализма. В статье выявлены факторы, оказывающие влияние на развитие форм собственности, к которым относятся развитие институциональной среды, снижение трансакционных издержек, спецификация прав собственности, новые технологии цифровой экономики.

Ключевые слова: формы собственности, теория прав собственности, институционализм, радикальный институциионализм, циифровая экономика, интернет-бизнес.

Институциональная и неоинституциональная теория предполагает выделение четырех базовых форм собственности, которые в современных условиях модифицируются и получают новое содержание.

Изучение форм собственности в неоинституциональной научной парадигме происходит в рамках теории прав собственности, теории фирмы и теории контрактов. В ее развитие внесли вклад Р.Коуз, А.Алчиян, Г.Демсец, Д.Норт, О.Уильямсон, Р.Познер, Э.Фуруботн, С.Пейович, К. Менар, П. Милгром, Д.Робертс. Вопросы связанные с функциями государства и государственной собственностью изучались в рамках институциональной теории государства, проблемы «безбилетников», в теории общественного выборы, экономическая теория конституции, благодаря таким экономистам как Дж.Бьюкенен, Г. Таллок, М. Олсон, Д. Мюллер, Р. Толлисон, У.Нисканен, В.Ванберг, Э. де Сото, Я.-Э.Лейн, П.Козловски, Э.Кругер, Б.Бейзингер, Р.Эклунд, Р.Толлисон, С.Медема, Т.Андерсон, П.Хилл, А. Эйдса, Т. Вердье

Российские экономисты также развивали вопросы институциональной теории, отражающие специфику российской экономики, к ним следует отнести Р. Капелюшникова, Р. Нуреева, А.Шаститко, А. Аузана, А. Олейника, В.Полтеровича,
Я. Кузьминова, В.Вольчика, М. Одинцову, М.Юдкевич, В.Тамбовцева, А. Нестеренко, М.Цирик, А. Заостровцев.

Формы собственности в институциональной теории выделяются на основе критерия доступа к ограниченным ресурсам. Традиционно рассматривают следующие четыре режимы доступа к ресурсам [4]:

1. Общая собственность или свободный режим доступа.

2. Режим коммунальной собственности.

3. Режим частной собственности.

4. Режим государственной собственности.

1. Форма собственности в виде свободного доступа характеризуется ситуацией, в которой ни один из экономических субъектов не обладает правом владения на ограниченный ресурс.

Для любого экономического агента, который видит ценность в данном ресурсе, есть возможность пользоваться ресурсом без согласования, без предварительного обсуждения этого с другими акторами, без необходимости санкционировать свои действия в тех или иных формах.

Вследствие существования открытого доступа к ограниченному ресурсу возникает его «сверхиспользование».

Режим собственности в виде свободного

\footnotetext{
* Статья написана в рамках фундаментальной научно-исследовательской работы (Регистрационный № НИОкР ВТК-ГЗ-ФИ-16-19) по теме: «Развитие теории отношений собственности в современном обществе» выполняемой по заказу Правительства Российской Федерации в ФГОБУ ВО «Финансовый университет при Правительстве Российской Федерации».
} 
доступа вызывает его «сверхиспользование». Это связано с тем, что каждый экономический субъект может присваивать выгоды, связанные с эксплуатацией ресурса, а издержки в связи с использованием ресурса лежаться на всех экономических агентов.

Блага свободного доступа характеризуются тем, что:

- Сохраняется режим при высоких издержках спецификации прав собственности. Издержки выше возможного дохода.

- Неустойчивый правовой режим собственности, эволюционирует либо в сторону частной собственности, либо государственной.

Модификация форм собственности свободного доступа происходит в результате трансформации отношений собственности и поиска наиболее эффективного использования природных ресурсов. Примером собственности свободного доступа в мировой экономике является воды и недра мирового океана, и ноосфера.

«Сверхиспользование» в рамках режима свободного доступа создает проблемы и угрозы для мирового океана;

- Промышленное рыболовство, массовый отлов рыбы и морепродуктов, из которых пятая часть приходится на нелегальную ловлю. В год это примерно 500 тысяч тонн.

- Загрязнение океана: нефтью и нефтепродуктами, пластиком (примерно 20 миллионов тонн ежегодно), который не разлагается, его поедают рыбы и погибают от этого. За последние сорок лет количество пластикового мусора увеличилось в Тихом океане в сто раз.

- Сточные воды, отходы сельского хозяйства.

- Захоронение жидких и твердых радиоактивных отходов.

- Отработанная вода, которая сбрасывается в океаны электростанциями, локально повышает температуру воды, что приводит к массовой гибели существ, не способных выжить при таких высоких температурах.

- Военные учения, испытания атомного оружия, создание военных баз разрушает экосистемы и наносит непоправимый вред.

Регулирование использования природных ресурсов мирового океана осуществляется Конвенцией ООН по морскому праву, которую подписали 170 государств. Но ее действие не решает правовых вопросов и проблемы «сверхиспользования» ресурсов океана.
Такие же вопросы связаны с ноосферой и космосом. Космическая экология выдвигает целый ряд вопросов, которые назрели уже сегодня или будут актуальны в ближайшей перспективе:

- губительное действие, которое оказывают продукты сгорания от ракетного топлива на ноосферу;

- разрушение озонового слоя в атмосфере;

- замусоривание космоса отслужившими деталями ракетно-космической техники;

- необходимость отчуждения под районы падения отделяющихся частей ракет-носителей по трассам их спусков больших участков земли.

2. Форма собственности, которую называют коммунальной собственностью. Её характеризует режим использования ограниченных ресурсов, когда исключительные права собственности принадлежат группе экономических агентов.

Право исключительности существует только для внешних членов сообщества и их групп (общин), внутри каждый из членов существует в режиме общей собственности.

Результаты коммунальной собственности заключаются в том, что, во-первых, внутри группы возникает проблема недоиспользования ресурса, в случае пропорционального распределения дохода, каждый участник группы пытается переложить на других производство; возникает проблема «безбилетника»; проблема острее в большей группе и при меньшей идентификации члена группы с ней; группа близка к распаду.

Во-вторых, коммунальная собственность отличается следующим чертами:

- Принцип распределения устанавливается на основе затраченных усилий, но это приводит к сверхиспользованию ресурса.

- Коммунальная собственность способна создать эффект свободного доступа.

- Группа малоэффективна прежде всего на внешнем рынке.

В-третьих, при коммунальной собственности может возникнуть система принятия согласованного решения, процедура голосования, распределительная демократия, агрегируются предпочтения и возникает решение, которое можно рассматривать как выражение общественного интереса.

При помощи процедуры голосования возможно предотвратить, с одной стороны проблему свободного доступа и «сверхиспользование» внутри группы, с другой стороны, предотвра- 
тить проблему безбилетника для обеспечения защиты этого ресурса от посягательств конкурирующих групп.

Сравнительные преимущества коммунальной собственности заключаются в относительно низких по сравнению с частной собственностью издержках по защите прав собственности, поскольку отношения исключительности направлены только на внешних субъектов хозяйствования.

Коммунальная собственность обладает жизнеспособностью при условии однородности общности людей и небольшой величине этой группы. Индивиды внутри группы должны идентифицировать себя как часть целого в отношении мыслей, слов, поступков.

Модификация форм собственности проходит в направлении развития специализации внутри группы и передачи полномочий отдельным членам.

Элеонора Остром [3], лауреат Нобелевской премии 2009 года, показала, что коммунальная собственность может быть успешной при определенных условиях. Общая собственность, управляемая отдельными группами людей, может брать на себя функции государственной собственности по созданию общественных и смешанных благ, как противовес частной собственности.

3. Частная форма собственности характеризуется правом принимать решение в отношении реализации правомочия для отдельного экономического агента, которому принадлежат все правомочия.

Весь пучок правомочий на ресурс сконцентрирован у одного человека.

Для частного собственника характерен предпринимательский тип поведения, преимущества которого заключаются в большей мотивации к рациональному использованию ресурсов, в поиске информации об альтернативных возможностях использования ресурсов.

Для поддержания режима исключительности частной собственности возможно использовать поддержку государства, это могут реализовывать сами субъекты права, при помощи социальных норм. В случае нарушения социальных правил и норм применяются экономические, юридические, этические санкции.

Препятствия для распространения системы частной собственности заключаются в высокие издержках защиты и спецификации прав собственности, наличии определенных идеологических и моральных установок в обществе, нормативных взглядов на мир.

Если в обществе доминирует представление о нерушимости права частной собственности, то это облегчает защиту прав частной собственности. Система ценностей общества влияет на выбор форм собственности. Отношения собственности в рамках частной собственности в рыночной экономике имеют особое значение, поскольку это самая предпринимательская форма.

Д.Бэлл выделяет основные черты частной собственности, которые она приобретает в результате экономического развития: «Важнейший исторический сдвиг - отделение общественной функции (или места человека в обществе, обычно задаваемого характером его занятий) от собственности. В западном обществе, особенно на капиталистической стадии развития, общественная функция могла быть трансформирована в собственность (землю, машины, акции и т.д.), которая сберегалась как богатство и передавалась по наследству в целях создания преемственности прав - привилегий, которые постепенно оформились в социальную систему. В новом обществе, которое формируется ныне, индивидуальная частная собственность теряет свое общественное предназначение (защиты труда в том смысле, как это понимал Дж. Локк, контроля или управления производством, вознаграждения за риск) и сохраняется лишь как функция» [1].

Под воздействием цифровых технологий частная форма собственности в наибольшей степени адаптируется и принимает много разновидностей, которые классифицируются в малый, средний и крупный бизнес.

Одной из важнейших проблем современной экономики является формирование эффективного частного собственника, выполняющего кроме производительной функции также социальную и коммуникативную.

Критическое отношение к рыночной экономической системе, основой которой является частная собственность, выражается в анализе экономических и социальных проблем, порождаемых крупной частной собственностью. Научные исследования в этом направлении осуществляют представители радикального институционализма, к которому относятся 
американские экономисты Уильям Даггер [5]: Уильям Уоллер, Эдит Миллер, Дж. Рон Стэнфилд, Рон Филлипс, Делл Чэмплин, Дженис Петерсон, Чарльз Уален, Даг Браун, Рик Тилман, Луис Юнкер, Говард Шерман.

Для радикального институционализма характерно отрицательное отношение к крупной частной собственности, в этом плане они продолжают традиции американского традиционного институционализма, родоначальником которого стал Торстейн Веблен, а затем продолжил Джон Кеннет Гэлбрейт

4. Форма государственной собственности в институциональной теории рассматривается как режим использования ограниченного ресурса, при котором исключительность доступа существует не только для аутсайдеров, но и для инсайдеров. При этом исключительность обязательно оформляется системой формальных правил.

В экономике формируются механизмы, частично компенсирующие негативное влияние оппортунистического поведения агентов в режиме государственной собственности. К ним относится «голосование руками»,

«голосование ногами», «конкуренция» со стороны других государств, распространение идеологии, препятствующей оппортунистическому поведению, внутренняя система контроля со стороны заинтересованных общественных организации.

Одним их первых теорию общественного сектора в мейнстриме стал разрабатывать Поль Самуэльсон [6].

Теорию общественного сектора развивали А. Пигу, Э. Линдаль, Р. Масгрейв, Дж.Ю.Стиглиц, Вернон Смит, Ч. Вулф, Ч. Тибу, Оутс, Р. Дж. Аронсо, Эн.Б. Аткинсон, Э.С. Савас, Д.Джонсон, Дж. Стевенс, Р.Холкомб, П.Ганинг, П.Мак-Натта, Алан
Дрейзен.

Среди российских экономистов Р.М.Нуреев, Л.И.Якобсон, Я.Кузьминов, М.Левина. В.Мау, В.Полтерович, В.Радаев, Л.С.Тарасевич, П.И.Гребенников, А.И. Леусский, А.В.Дьячкова, Л.А.Ефимова, П.С.Звягинцев[2]. и др. В настоящий момент теория общественных благ активно развивается и в рамках институциональной теории.

Модификация государственной и частной форм собственности в аспекте теории общественных и частных благ, заключается в появлении сложных совместных форм предпринимательства. К таким формам относится государственно-частное партнерство (ГЧП), которое развивается в мировой и российской практике.

На ряду с экономическими и технологическими факторами существенную роль играют институциональные факторы. Создание благоприятной среды для предпринимательства, развитость трансакционного сектора, создали благоприятные условия в экономике развитых стран для развития малого и среднего бизнеса, особенно эта тенденция ускорилась в последние 20 лет. В РФ проводится программа по поддержке малого и среднего бизнеса, но пока его доля занимает только $22 \%$ в ВВП. Развитие предпринимательства связано с традициями и гистерезисом в отношениях собственности, которые были представлены в XX веке для нескольких поколений только государственной и общенародной собственностью. Для увеличения численности малого и среднего предпринимательства потребуется «выращивание» институтов, которые будут способствовать распространению предпринимательства среди новых поколений, как возможность реализации своих бизнес-идей, свободы действий и выбора.

\section{Библиографический список}

1. Бэлл Д. Грядущее постиндустриальное общество - - Москва: Академия, 1999.С.16

2. Звягинцев П. С. Управление государственной собственностью как фактор влияния на инновационное развитие экономики России // Экономические науки. 2019. № 9 (178) C.76-81. DOI: 10.14451/1.178.76.

3. Остром Э. Управляя общим. Эволюция институтов коллективной деятельности.- М.: Мысль, ИРИСЭН, 2011.

4. Шаститко А. Е. Новая институциональная экономическая теория. Изд.4-е, перераб. и доп. М.: ТЕИС, 2010.

5. Dugger, W. Radical Institutionalism: Basic Concepts. //Review of Radical Political Economics, 1988 20(1), 1-20; Dugger, W. Radical Institutionalism: Contemporary Voices. Westport, CT: Greenwood Press. 1989.

6. Samuelson P. The Pure Theory of Public Expenditure // Journal of Political Economy.- 1954. 